Relations industrielles

Industrial Relations

\title{
Corey Rosen and Karen M. Young, eds. Understanding Employee Ownership
}

\section{Richard J. Long}

Volume 47, numéro 2, 1992

URI : https://id.erudit.org/iderudit/050780ar

DOI : https://doi.org/10.7202/050780ar

Aller au sommaire du numéro

Éditeur(s)

Département des relations industrielles de l'Université Laval

ISSN

0034-379X (imprimé)

1703-8138 (numérique)

Découvrir la revue

Citer ce compte rendu

Long, R. J. (1992). Compte rendu de [Corey Rosen and Karen M. Young, eds. Understanding Employee Ownership]. Relations industrielles / Industrial Relations, 47(2), 381-383. https://doi.org/10.7202/050780ar

Tous droits réservés @ C Département des relations industrielles de l'Université Laval, 1992
Ce document est protégé par la loi sur le droit d'auteur. L’utilisation des services d'Érudit (y compris la reproduction) est assujettie à sa politique d'utilisation que vous pouvez consulter en ligne.

https://apropos.erudit.org/fr/usagers/politique-dutilisation/ 
Understanding Employee Ownership, edited by Corey Rosen and Karen M. Young, Ithaca, New York, ILR Press, 1991, 242 p., ISBN 0-87546-171-9

The purpose of this book, edited by the two founders of the National Center for Employee Ownership (NCEO) in the United States and published on its tenth anniversary, is to provide "objective, reliable information" about employee ownership - its merits and demerits, when it is or is not appropriate, and how to make it work best. In this purpose, they succeed admirably. While they are candid about their underlying views about employee ownership ("we think it offers the best hope for combining the goals of social justice with the need for economic efficiency", p. vi), this does not prevent them from presenting a picture that includes both resounding successes and dismal failures. Indeed, they argue that attempts to gloss over the shortcomings of employee ownership and negative experiences with it not only undermine the credibility of those advocating the concept, but also squander opportunities to gain more knowledge about the concept.

This book is organized in seven chapters, each dealing with a specific aspect of employee ownership (EO), and two appendices. The first chapter, written by Corey Rosen, provides an excellent summary of the empirical evidence on the results of employee ownership, in terms that can be understood by the lay reader, as well as his thoughts on its "prospects and promise". He starts the chapter by first charting the astounding growth of EO during the last fifteen years in the United States - where one in nine private sector employees is now a part owner of his/her firm - and then provides a brief overview of U.S. employee ownership legislation as it has evolved since 1974, when the first federal legislation providing favourable tax treatment for "Employee Stock Ownership Plans" (ESOPs) was enacted.

Next, he summarizes the evidence on the consequences of EO for the distribution of wealth in U.S. society and for corporate performance and governance. He finds that, on average, ESOPs do result in a more equitable distribution of wealth, a more democratic governance of corporations, and, when combined with participatory management, better corporate performance. He also tackles possible abuses of ESOPS, acknowledging that they can and do exist, and suggesting ways to minimize them. While not dismissing these abuses, he argues that the most important yardstick is whether ESOPS do more good than harm, and finds the evidence overwhelmingly positive.

The second chapter, by Darien McWhirter, provides an excellent description and explanation of the complex ESOP legislation, in practical terms. The third chapter, by See Steiner, follows up on this by discussing alternative employee ownership plans - those not set up under the ESOP legislation. This is accompanied by an excellent discussion of the pro's and con's of setting up a plan inside or outside of the ESOP legislation.

In the fourth chapter, Karen Young describes "Theory O: The Ownership Theory of Management", arguing that a break from traditional management practice is necessary for employee ownership to have a beneficial impact on company performance. "Theory $\mathrm{O}$ " is a type of participative management, fleshed out with some specific management principles and practices that have 
worked particularly well in employee owned companies. Managers will find the contents of this chapter very concrete and usable.

In the fifth chapter, Lauren Segarra provides a convincing discussion of how employee ownership can be used as an important building block in the community economic development process, because of its ability to simultaneously address both social and business goals, and also includes a description of the programs implemented by the governments of various U.S. states to support employee ownership. In chapter six, Gianna Durso and Raul Rothblatt discuss the state of employee ownership in countries other than the United States, noting that the idea is becoming increasingly popular in countries as diverse as Great Britain, China, and the Soviet Union, as well as third world countries such as Egypt and Costa Rica. The greatest potential, they argue, may be in the new democracies of Eastern Europe, where employee ownership can play a major role in the privatization of government owned companies, and may help to reconcile the need to create a market economy based on a strong private sector with many of the beliefs and ideologies long held in those countries.

The very brief seventh chapter, by Karen Young and Corey Rosen, asks what is in the future for employee ownership, concluding that the key is in the effective economic performance, and hence, effective management, of employee owned firms. That is followed by two appendices - "A Primer on Business" by Corey Rosen, and an annotated bibliography of documentary evidence regarding employee ownership. The "Primer" provides an excellent description of the way in which the United States business system works explaining everything from "capital" to "leveraged buyout" all in eleven wellwritten pages, utilizing several continuing examples.

Indeed, a halimark of this book is its ability to render complex concepts and legal terminology into not only an understandable form, but also one that is almost a pleasure to read, without any sacrifice in rigour or oversimplification. A "401(k) plan"? No problem. A "leveraged recapitalization"? Piece of cake. All in all, this book lives up to its title, and is readily accessible to anybody with ordinary reading skills.

Clearly, this book has not been aimed at academicians - it contains not a single conceptual framework explaining why or how employee ownership works in theory - but instead embodies the practical experiences of hundreds of companies that have tried the concept. It is clear that the authors are fully conversant with the most important empirical research conducted by others they summarize it smoothly and painlessly, with unobtrusive footnotes documenting sources - but the majority of the book is based on the ten years of research and analysis conducted by the NCEO.

This book is not intended as critique of the current United States legislative framework for employee ownership. Others have done that (e.g. J.R. Blasi, Employee Ownership: Revolution or Ripoff? New York, Ballinger, 1988) and Rosen and Young clearly feel that it is more productive to focus on what has, is, and can be done under the current legislative framework than to rail away at perceived deficiencies in the legislation. Indeed, throughout the book, the authors have consciously opted to take a "glass is half full" - not half empty perspective. While employee ownership has not resolved all of the problems 
currently facing the U.S. economy, nor can it be expected to, the advance of employee ownership during the last ten years is truly astonishing, and Rosen and Young are right to point that out. If read widely, as it deserves to be, this book has the potential to dispel much of the confusion and misinformation that currently mars the general understanding of this important concept.

Richard J. LONG

University of Saskatchewan

The Climate of Workplace Relations, by Ali Dastmalchian, Paul Blyton and Raymond Adamson, Routledge, London and New York, 1991, 215 p., ISBN 0-415-03738-7.

Ce volume, rédigé sous la forme d'une thèse ou d'un rapport de recherche, vise à présenter un nouveau modèle des relations du travail où le climat entre les parties peut grandement influencer la gestion des ressources humaines, la structure organisationnelle et les politiques touchant les individus.

Le volume comprend sept chapitres. Le premier chapitre fait un survol du concept de relations industrielles et de celui des théories des organisations. II présente les intentions et le plan de la recherche. Le second chapitre aborde les changements et la dynamique des relations du travail au sein des organisations. Les auteurs présentent les changements dans un contextes où évolue les relations du travail, la structure industrielle, la composition de la main-d'oeuvre et l'organisation syndicale. Tous ces changements conduisent les auteurs à s'interroger sur l'avenir des relations du travail. La diminution du nombre de syndiqués, la précarité des emplois, les nouvelles approches en gestion peuvent-elles réduire l'importance des relations du travail? Les auteurs pensent que les relations du travail demeureront aussi importantes dans l'avenir, cependant, il faudra repenser les mécanismes et créer un climat où les parties pourront échanger et collaborer.

Le troisième chapitre s'attarde au concept de climat. Une revue assez complète des recherches publiées sur le sujet y est présentée. Cependant, certains auteurs importants sont absents: Friendlander et Margulies (1969), Meyer (1969), Prichard et Karasik (1973), Gavin (1975) et Drexler (1977). Les auteurs proposent un modèle d'analyse du climat des relations du travail. Ce modèle s'inspire de l'approche systémique où l'on retrouve comme intrants le contexte organisationnel, la structure, les politiques de ressources humaines et le contexte des relations du travail. La transformation des intrants se résume à l'importance attribuée aux activités et au processus des relations du travail. Les extrants se composent des incidents, du taux de roulement, de l'absentéisme, du succès des négociations, de la perception des syndicats et de la direction face aux relations du travail. Finalement, un processus de rétroaction existe entre les extrants et les intrants. L'approche systémique est très répandue en relations industrielles, néanmoins, l'approche stratégique où l'on tient compte de l'environnement externe et de l'environnement interne en considérant la mission, les valeurs, la culture, les forces et les faiblesses de l'organisation aurait sans doute pu enrichir ce modèle. Ce chapitre contient une note où les auteurs présentent les relations entre le concept de climat organisationnel et celui de 